\title{
Twenty-five tonnes of high quality forages annually in Canterbury
}

\author{
T. J. FRASER ${ }^{1}$, T. L. KNIGHT ${ }^{1}$, I. M. KNOWLES ${ }^{1}$ and M. G. HYSLOP ${ }^{2}$ \\ ${ }^{1}$ AgResearch, Canterbury Agriculture and Science Centre, P. O. Box 60, Lincoln \\ ${ }^{2}$ Heinz-Wattie's Ltd, P. O. Box 16083, Christchurch \\ tom.fraser@agresearch.co.nz
}

\begin{abstract}
Recent developments in cereal breeding for forage production have given the potential to greatly increase annual forage dry matter (DM) production. This paper reports on the findings from two cereal forage production trials on irrigated Canterbury land. Trial 1 studied the potential of a range of single and multi-grazed cereal forages over a 9 month period to produce high yields and quality from both grazing and whole-crop silage forage. Trial 2 studied the suitability of different cereal/ legume combinations for green-chop silage grown over a three month summer period. These two cereal forage systems, when combined in a 12 month period, produced in excess of 25 tonnes of high quality forage per hectare, almost double the DM production achieved using current perennial pasture based systems. Trial 1 showed no significant difference in the total DM produced by either single or multi-graze treatments. In Trial 2 pea/cereal combinations produced over $6 \mathrm{tDM} / \mathrm{ha}$. Due to an earlier final harvest the multi-graze system is more easily combined with the summer crop and more likely to produce a lower cost and more sustainable forage system. Animal performance on forage produced in Trial 1 showed that dairy calves can grow well on cereal forages during winter.
\end{abstract}

Keywords: cereal, feed supplements, forage, forage yield, legume, silage

\section{Introduction}

Intensification of pastoral farming in Canterbury has occurred rapidly in recent years. There have been two major changes in land use. Firstly, during the 1990's, large areas changed from dryland sheep to irrigated dairying. Secondly, recent improved sheep meat returns have driven increased production targets on dryland and irrigated sheep properties. These changes have led to a requirement for increased quantity and quality of herbage grown on-farm.

Historically, the majority of the intensive pastoral area of New Zealand is based on ryegrass/white clover pastures. In Canterbury under irrigation these peak at around $15 \mathrm{t}$ dry matter (DM)/ha on the light stony soils (Moss 1987) and $17 \mathrm{t} \mathrm{DM/ha} \mathrm{on} \mathrm{the} \mathrm{more} \mathrm{productive}$ heavy soils (Fraser \& Vartha 1979). Previous cereal forage research (Martin \& Knight 1987) had primarily been concerned with grazing cereal cultivars bred for grain production.

The introduction of cereal cultivars bred for forage production and suitability for whole-crop silage (de Ruiter 2001; de Ruiter et al. 2002), and improved knowledge of double cropping systems, has revealed the potential to substantially exceed the annual herbage production of current perennial pasture based forage systems for grazing both in situ and conserved forage. Jermyn et al. (1993) reported that peas were compatible with cereal crops while Neizen et al. (1998) produced high quality silage with high proportions of the legume sulla in the mixture and also found that ensiling herbage using a mini silo method produced excellent silage.

This paper will report on two forage trials, conducted on separate sites but which have the potential for succession in a 12 month period, and the ability to produce in excess of $25 \mathrm{t} \mathrm{DM} / \mathrm{ha}$ of high quality forage. These trials were carried out independently, the first was a two year study conducted at Winchmore Research Station in mid-Canterbury on irrigated light soils. The aim of this trial was to demonstrate the production potential of forage cereals. Scenarios in this study included either single or multi-graze systems for wintering of stock, and included conservation for whole-crop silage. Animal performance measurements were recorded over the winter grazing periods.

The second trial investigated the potential to increase forage production where a window of opportunity exists between the removal of summer harvested crops and autumn sowing of subsequent crops. This plot trial was conducted at the AgResearch Lincoln farm and investigated a range of cereal/legume mixtures grown under irrigation over the January to March period. Measurements included herbage dry matter accumulation and testing the mixtures for conservation as silage.

In addition to these two trials, cereal whole-crop silage from the Winchmore trial and forage pea/triticale silage grown at Lincoln in association with the plot trial was fed to milking cows in autumn. The results from this feeding trial are reported by Stevens et al. (2004).

\section{Methods}

\section{Trial 1 - Winchmore}

Site

Trial 1 was sited at Winchmore Research Station on a Lismore stony silt loam under border strip irrigation. 
Table 1 Botanical and common names of cultivars used in Trial 1.

\begin{tabular}{lccc}
\hline Treatment & Botanical name & Common Name & Cultivar \\
\hline Perennial pasture & Lolium perenne L. & Perennial ryegrass & Nui \\
Perennial pasture & Trifolium repens L. & White clover & Huia \\
Multi-graze 2002 & Lolium multiflorum L. & Italian ryegrass & Tama \\
Multi-graze 2003 & Lolium multiflorum L. & Italian ryegrass & Warrior \\
Single-graze & Avena sativa L. & Oat & Hokonui \\
Single-graze \& spring silage & Avena sativa L. & Oat & Stampede \\
Single-graze & Avena sativa L. & Oat & Makuru \\
Multi- graze \& spring silage & Triticosecale & Triticale & DoubleTake \\
Spring silage & Triticosecale & Triticale & Rocket \\
Single-graze & Triticosecale & Triticale & 4992.9 .2 \\
Spring silage & Hordeum vulgare L. & Barley & Boss \\
Multi-graze (not used for silage) & Secale cereale L. & Ryecorn & Rahu \\
\hline
\end{tabular}

Table 2 Treatments used in Trial 1 in 2002/03, between brackets variations for 2003/04.

\begin{tabular}{|c|c|c|}
\hline & Autumn treatment & Spring treatment \\
\hline Single-graze & $\begin{array}{l}4992.9 .2 \text { triticale } \\
\text { Stampede oats } \\
\text { Hokonui oats }\end{array}$ & $\begin{array}{c}\text { DoubleTake triticale (Rocket) } \\
\text { Stampede oats (Rocket) } \\
\text { Rocket triticale }\end{array}$ \\
\hline Multi-graze & $\begin{array}{c}\text { Tama Italian ryegrass (Warrior) } \\
\text { Perennial ryegrass/ white clover } \\
\text { Tama plus DoubleTake triticale } \\
\text { DoubleTake triticale } \\
\text { Rahu ryecorn }\end{array}$ & $\begin{array}{c}\text { Whole-crop silage } \\
\text { Whole-crop silage } \\
\text { Whole-crop silage } \\
\text { Whole-crop silage } \\
\text { Boss barley whole-crop silage (Rocket) }\end{array}$ \\
\hline
\end{tabular}

The trial was conducted over a two year period from March 2002 to January 2004. Over the period of the trial soil fertility showed little change; $\mathrm{pH}$ stayed at 6.0 , Olsen phosphorus (P) dropped from 23 to $21 \mu \mathrm{g} / \mathrm{ml}$, quick test (QT) potassium $(\mathrm{K})$ from 5 to 4 and sulphate-sulphur (S) from 6 to $5 \mu \mathrm{g} / \mathrm{g}$.

The trial area was laser-levelled and re-bordered during summer 2002 just prior to sowing. Eight treatments replicated three times were allocated in a complete randomised block design. Plots were large in size $(0.33$ ha) to achieve a minimum grazing period of 21 days and for demonstration purposes. The species and cultivars used are listed in Table 1.

Autumn sowings occurred in mid-March with fungicide treated seed. Cereal sowing rates were adjusted by seed weight and germination $\%$ to achieve 300 plants/ $\mathrm{m}^{2}$. The grass treatments were Italian ryegrass (sown at $30 \mathrm{~kg} / \mathrm{ha}$ ) and Nui perennial ryegrass (sown at $20 \mathrm{~kg} / \mathrm{ha}$ with $3 \mathrm{~kg} /$ ha Huia white clover). The perennial ryegrass/ white clover pasture was considered to be a control.

After grazing in mid-winter, the single-graze plots were sprayed with 2 1/ha of Roundup herbicide and Pulse, then conventionally cultivated before sowing the cereals in early October. Insecticide treated cereal seed was sown at a rate to achieve 300 plants $/ \mathrm{m}^{2}$.

In autumn of both years $175 \mathrm{~kg} / \mathrm{ha}$ of Cropmaster 15 $(\mathrm{N}: \mathrm{P}: \mathrm{K}: \mathrm{S}, 15: 10: 10: 8)$ was applied at sowing with a further $100 \mathrm{~kg} /$ ha of urea $(46 \% \mathrm{~N})$ applied 4 weeks after sowing. Spring sown plots received an application of $150 \mathrm{~kg} /$ ha of Cropmaster 15 at sowing and subsequently two applications of $190 \mathrm{~kg} / \mathrm{ha}$ of urea. All spring sown cereals had Axall herbicide (3 1/ha) and Opus fungicide (300 ml/ha) applied in mid-November in both years and in mid-December 2002 an application of Amistar fungicide ( $700 \mathrm{ml} / \mathrm{ha})$, Opus $(300 \mathrm{ml} / \mathrm{ha})$ and Piromor 50 insecticide $(200 \mathrm{ml} / \mathrm{ha})$. The autumn sown cereals had an application of Opus fungicide $(300 \mathrm{ml} / \mathrm{ha})$ in mid-December in both years. All cereal silage crops had straw shortener (1.251/ha Cycocel 750) applied in spring.

Plots were irrigated once in autumn and four times during spring/early summer. Border strip irrigation applied approximately $100 \mathrm{~mm}$ water/irrigation with 50 $\mathrm{mm}$ retained in the topsoil for plant use.

Multi-grazed treatments were grazed in May and earlySeptember and single-grazed treatments were grazed in August then cultivated and resown. The same group of animals to be used on all grazings, therefore enabling animals to become accustomed to a cereal forage based diet.

\section{Treatments}

Cultivar treatments used in 2002/2003 and 2003/2004 are presented in Table 2. In 2003/2004 Makuru oats was added to the single-graze treatments sown in autumn and all single-graze treatments were spring sown in Rocket triticale for whole-crop silage. Also Warrior Italian 
ryegrass replaced Tama in 2003/2004 and the Tama plus DoubleTake treatment in 2002/2003 was removed in the following year. There was also a change in the Rahu ryecorn treatment, Rocket triticale was used as the spring crop in 2003/2004 in place of Boss barley.

\section{Forage yield}

Pre and post grazing forage yield was determined by cutting two $0.375 \mathrm{~m}^{2}$ representative quadrats to $1 \mathrm{~cm}$ above ground level. Total forage yield at time of silage harvest was determined by cutting ten $1 \mathrm{~m}$ rows of representative areas to $1 \mathrm{~cm}$ height. The residual after silage removal was determined by cutting (to $1 \mathrm{~cm}$ ) five $1 \mathrm{~m}$ rows of representative stubble. Silage harvest was conducted at the milky dough stage of grain maturity.

\section{Grazing management}

The pre grazing forage mass was used to calculate the number of calves (nine month old dairy heifers) allocated to each treatment so that each animal received a similar forage allowance. The calves were weighed at the start and end of each grazing period. Animals were removed when forage biomass reached $500 \mathrm{~kg} \mathrm{DM} / \mathrm{ha}$ from the multi-grazed cereal and annual grass and $1000 \mathrm{~kg} \mathrm{DM} /$ ha in the perennial ryegrass plots. The single-grazed treatments were grazed to very low residuals $(<500 \mathrm{~kg}$ $\mathrm{DM} / \mathrm{ha}$ ). The higher residual on the perennial ryegrass was due to higher tiller density and DM \%.

\section{Trial 2 - Lincoln}

\section{Site}

The plot trial at Lincoln investigated a range of cereal/ legume mixtures grown over the January to March period. The trial was sited at the AgResearch Lincoln farm on Wakanui silt loam soil and was drilled on 15 January 2003 into a cultivated seedbed using a cone seeder. Soil test results prior to sowing were; $\mathrm{pH} 5.6, \mathrm{P} 19 \mu \mathrm{g} / \mathrm{ml}$, QT K 18 and sulphate-S $11 \mu \mathrm{g} / \mathrm{g}$.

The trial was a split plot design with four replicates. There were four legume main treatments and six cereal and no cereal sub-treatments. Plot size was $15 \mathrm{~m}$ x $3 \mathrm{~m}$. Species and sowing rates (Table 8 ) were chosen to give a range of legume/cereal mixes to achieve equal portions of cereal and legume at harvest. Sowing rates were adjusted to achieve $60,20,60$ and 60 plants $/ \mathrm{m}^{2}$ for peas, beans, cereals and grass, respectively, allowing for seed weight and germination \%. Prior to drilling, $150 \mathrm{~kg} / \mathrm{ha}$ superphosphate (N:P:K:S, 0:9:0:11) was broadcast and three irrigations were applied with a travelling sprinkler irrigator from mid-January to early-February. Twentyfive $\mathrm{mm}$ of water was applied at the first irrigation and $50 \mathrm{~mm}$ at the second and third. The pea crop developed powdery mildew (Erysiphe polygoni DC) in early-March and all pea and pea mixture plots were sprayed with 160 $\mathrm{ml} /$ ha of Folicur fungicide in $120 \mathrm{l} /$ ha water. No further disease control was required on any treatments.

\section{Herbage determinations}

On 25 March 2003 herbage from three $1 \mathrm{~m}$ row lengths was cut from each plot and dissected into legume and cereal. These components were weighed green, sub sampled and dried at $80^{\circ} \mathrm{C}$ in a forced-air oven, for 48 hours, for dry matter determination.

\section{Silage}

At the end of March forages were cut with a rotary mower and wilted overnight. Herbage from each sub plot was chopped to approximately $25 \mathrm{~mm}$ lengths. Herbage was compressed to a common density by a hand operated lever system into a 201 plastic bucket lined with a heavy plastic bag, following the method of Niezen et al. (1998). This plastic bag was tied off as tightly as possible and the bucket lid taped on. These buckets were stored under cover and out of direct sunlight.

In May 2003, the buckets from replicate one were opened and assessed for colour, mould and odour. Buckets were emptied in a row, with $2 \mathrm{~m}$ between heaps, onto a bare runoff paddock and 200 ewes allowed access. After 10 hours (overnight) their preferences were recorded.

Table 8 Crop species, cultivars and sowing rates used in Trial 2.

\begin{tabular}{lccc}
\hline Crop & Botanical name & Cultivar & Sowing rate $(\mathrm{kg} / \mathrm{ha})$ \\
\hline Peas & Pisum sativum $\mathrm{L}$. & Magnus & 220 \\
Dwarf beans & Phaseolus vulgaris $\mathrm{L}$. & Labrador & 150 \\
Runner beans & Phaseolus coccineus $\mathrm{L}$. & Scarlet & 190 \\
Haricot beans & Phaseolus vulgaris $\mathrm{L}$. & Navy bean & 170 \\
Barley & Hordeum vulgare $\mathrm{L}$. & Boss & 28 \\
Wheat & Triticum aestivum $\mathrm{L}$. & Sapphire & 24 \\
Oats & Avena sativa L. & Stampede & 27 \\
Triticale & Triticum $(x$ Triticosecale) & DoubleTake & 28 \\
Italian ryegrass & Lolium multiflorum $\mathrm{L}$. & Tabu & 7 \\
Ryecorn & Secale cereale L. & Rahu & 13 \\
\hline
\end{tabular}


Table 3 Trial 1 - herbage yields (DM kg/ha) for the single-graze treatment.

\begin{tabular}{|c|c|c|c|c|}
\hline Autumn cultivar & Grazed yield & Spring cultivar & Silage yield & Total yield \\
\hline \multicolumn{5}{|l|}{$2002 / 2003$} \\
\hline 4992.9.2 & $7130 b^{1}$ & DoubleTake & $16875 \mathrm{a}^{1}$ & $24005 a^{2}$ \\
\hline Stampede & $7400 \mathrm{~b}$ & Stampede & $21280 \mathrm{a}$ & $28680 \mathrm{~b}$ \\
\hline Hokonui & 5960 a & Rocket & 15579 a & 21539 a \\
\hline \multicolumn{5}{|l|}{$2003 / 2004$} \\
\hline 4992.9.2 & $2939 a^{1}$ & & & \\
\hline Stampede & 3954 a & & & \\
\hline Hokonui & 3536 a & & & \\
\hline Makuru & 2945 a & & & \\
\hline
\end{tabular}

Table 4 Trial 1-herbage yield (DM kg/ha) for the multi-graze treatment. Grazing 1 - herbage accumulated from sowing till first grazing. Grazing 2 - herbage accumulated between grazings 1 and 2, excluding grazing 1 residual.

\begin{tabular}{|c|c|c|c|c|c|}
\hline Cultivar & Grazing 1 & Grazing 2 & Graze total & Silage & Total yield \\
\hline \multicolumn{6}{|l|}{$2002 / 2003$} \\
\hline Italian & 2460 & 1320 & $3780 \mathrm{~b}$ & not sampled & \\
\hline Nui & 1600 & 500 & $2100 \mathrm{a}$ & not sampled & \\
\hline Italian/DoubleTake & 3430 & 1140 & $4570 \mathrm{c}$ & not sampled & \\
\hline DoubleTake & 3800 & 1240 & $5040 \mathrm{~cd}$ & 18052 & \\
\hline Rahu & 4600 & 1200 & $5820 d$ & $15736^{a}$ & \\
\hline \multicolumn{6}{|l|}{$2003 / 2004$} \\
\hline Italian & 1670 & 1640 & 2803 a & $12370 \mathrm{a}$ & 15675 \\
\hline Nui & 1720 & 1560 & $2788 \mathrm{a}$ & $12757 \mathrm{a}$ & 15545 \\
\hline DoubleTake & 2710 & 900 & 3116 a & $17784 \mathrm{a}$ & 21394 \\
\hline Rahu & 2170 & 1730 & 2909 a & $11739^{\mathrm{b} a}$ & 15639 \\
\hline $\begin{array}{l}\text { Means with the same le } \\
\text { a Boss barley spring sc } \\
{ }^{b} \text { Rocket triticale spring }\end{array}$ & $\begin{array}{l}\text { significant } \\
\text { rop. } \\
\text { e crop. }\end{array}$ & $P<0.001$ & & & \\
\hline
\end{tabular}

\section{Data analysis}

All data sets were analysed by analysis of variance using Genstat for Windows 7th edition (VSN International Ltd).

\section{Results \\ Trial 1}

The data sets are presented for each year individually because of changes in the cultivars used.

\section{Single-graze}

In Year one, there were significant differences between the total amounts of DM produced from cultivars in the single-grazing/ spring silage cropping system (Table 3 ). The autumn sown Stampede oats and the 4992.9.2 triticale produced more than Hokonui oats at the single-graze but the spring sown silage crops were similar. The Stampede treatment produced more, at over $28.6 \mathrm{t} / \mathrm{ha}$, than the Hokonui oats/Rocket triticale ( $21.5 \mathrm{t} / \mathrm{ha})$.

There were no significant differences in grazing forage biomass for single-graze cultivars in year two (Table 3 ). Similarly there were no differences in spring yields of crops sown for silage.

\section{Multi-graze}

Measurements were not taken for DM produced from spring silage from all treatments, therefore silage yield and total DM produced for the year could not be determined. However, as an indication of potential accumulated yield, DoubleTake triticale produced 18000 $\mathrm{kg} \mathrm{DM} /$ ha for a total in excess of $23000 \mathrm{~kg} \mathrm{DM} / \mathrm{ha} / \mathrm{yr}$. The total forage masses produced by Rahu ryecorn and DoubleTake triticale were in excess of $5000 \mathrm{~kg} \mathrm{DM} / \mathrm{ha}$ whereas the perennial ryegrass produced significantly less at $2000 \mathrm{~kg} \mathrm{DM} / \mathrm{ha}(\mathrm{P}<0.001)$.

There were no significant differences in forage production in the second year (Table 4 ) between cultivars used in the multi-grazing systems although the DoubleTake treatment produced over $21 \mathrm{t} / \mathrm{ha}$ DM.

\section{Animal performance}

Trial 1

Animals grazing Hokonui grew significantly less (Table 5) than the other cultivars. 
Table 5 Trial 1 - single-graze treatment liveweight gain (g/head/day) in 2003/2004.

\begin{tabular}{lc}
\hline Cultivar & Liveweight gain \\
\hline 4992.9 .2 triticale & $272 \mathrm{~b}$ \\
Hokonui oats & $141 \mathrm{a}$ \\
Makuru oats & $240 \mathrm{~b}$ \\
Stampede oats & $288 \mathrm{~b}$ \\
\hline
\end{tabular}

Means with the same letter are not significantly different $\mathrm{P}<0.01$.

Table 6 Trial 1 - multi-graze treatment liveweight gain (g/head/day).

\begin{tabular}{lcc}
\hline Cultivar & Grazing 1 & Grazing 2 \\
\hline 2002/2003 & & \\
Italian ryegrass & $741 \mathrm{~b}$ & $695 \mathrm{~b}$ \\
Nui ryegrass & $278 \mathrm{a}$ & $264 \mathrm{a}$ \\
Italian/DoubleTake & $669 \mathrm{~b}$ & $797 \mathrm{~b}$ \\
DoubleTake triticale & $691 \mathrm{~b}$ & $691 \mathrm{~b}$ \\
Rahu ryecorn & $693 \mathrm{~b}$ & $253 \mathrm{a}$ \\
2003/04 & & \\
Italian ryegrass & $628 \mathrm{c}$ & $598 \mathrm{c}$ \\
Nui ryegrass & $341 \mathrm{a}$ & $218 \mathrm{a}$ \\
DoubleTake triticale & $485 \mathrm{~b}$ & $561 \mathrm{C}$ \\
Rahu ryecorn & $434 \mathrm{~b}$ & $271 \mathrm{~b}$ \\
\hline
\end{tabular}

Means with the same letter are not significantly different $P<0.001$.

Table 7 Trial 1 - animal performance (kg liveweight gain/ha/day) for the multi-graze treatment.

\begin{tabular}{lcc}
\hline Cultivar & Grazing 1 & Grazing 2 \\
\hline 2002/2003 & & \\
Italian ryegrass & $7.6 \mathrm{~b}^{1}$ & $9.6 \mathrm{~b}^{1}$ \\
Nui ryegrass & $3.3 \mathrm{a}$ & $2.7 \mathrm{a}$ \\
Italian/DoubleTake & $8.8 \mathrm{~b}$ & $9.2 \mathrm{~b}$ \\
DoubleTake triticale & $10.3 \mathrm{~b}$ & $8.4 \mathrm{~b}$ \\
Rahu ryecorn & $11.3 \mathrm{~b}$ & $3.1 \mathrm{a}$ \\
2003/2004 & & \\
Italian ryegrass & $8.9 \mathrm{a}^{2}$ & $9.0 \mathrm{~b}^{2}$ \\
Nui ryegrass & $6.7 \mathrm{a}$ & $3.9 \mathrm{a}$ \\
DoubleTake triticale & $9.3 \mathrm{~b}$ & $10.6 \mathrm{~b}$ \\
Rahu ryecorn & $6.7 \mathrm{a}$ & $4.4 \mathrm{a}$ \\
\hline
\end{tabular}

Means with the same letter are not significantly different ${ }^{1} \mathrm{P}<0.01$, ${ }^{2} \mathrm{P}<0.05$.

Because of a snowfall during grazing there was no single-graze animal data from Year one.

There was a significant difference between cultivars (Table 6) in the amount of per head liveweight (LW) gain over the grazing periods. DoubleTake, DoubleTake/Italian ryegrass and Italian ryegrass all produced around $700 \mathrm{~g} /$ head/day whereas animals grazing perennial pasture produced significantly less at both grazings and Rahu ryecorn less at the second grazing. Liveweight gain on a per hectare basis (Table 7) followed a similar pattern.

The pattern of animal growth rates in Year 2 (Table 6) were very similar to the first year with DoubleTake and Italian ryegrass producing significantly better results. On a total animal liveweight gain per hectare basis, perennial pasture, Rahu ryecorn and Italian ryegrass (Table 7) all produced between $170-260 \mathrm{~kg} \mathrm{LW}$ gain/ha, whereas DoubleTake triticale was significantly higher than all other forages at the first grazing and higher than Nui ryegrass and Rahu ryecorn at the second.

\section{Trial 2}

Legume and total yield from the pea treatments was significantly higher than any of the bean treatments (Table 9). Only the pea mixtures produced equal portions of legume and cereal whereas the bean mixtures were dominated by the cereals. Triticale, barley and oats yields were similar and significantly higher $(\mathrm{P}<0.05)$ (Table 9) than that of wheat and ryecorn. Italian ryegrass had a significantly lower yield than the cereals but there was potential for further growth after the silage was cut.

Table 9 Trial 2 - forage yields of the main effects (kg DM/ha).

\begin{tabular}{lccc}
\hline & $\begin{array}{c}\text { Legume } \\
\text { yield }\end{array}$ & $\begin{array}{c}\text { Cereal } \\
\text { yield }\end{array}$ & $\begin{array}{c}\text { Total } \\
\text { yield }\end{array}$ \\
\hline Legumes & & & \\
Peas & 3735 & 2744 & 6112 \\
Dwarf beans & 1210 & 4435 & 5006 \\
Runner beans & 951 & 5083 & 5308 \\
Haricot beans & 1225 & 4900 & 5425 \\
LSD (P<0.05) & 378 & 492 & 560 \\
Cereals & & & \\
Nil & 3378 & 0 & 3378 \\
Barley & 1068 & 5371 & 6439 \\
Wheat & 1665 & 4108 & 5772 \\
Oats & 1289 & 5695 & 6984 \\
Triticale & 1291 & 5488 & 6779 \\
Italian ryegrass & 2271 & 1660 & 3931 \\
Ryecorn & 1499 & 3466 & 4965 \\
LSD (P<0.05) & 363 & 534 & 541 \\
\hline
\end{tabular}

When the silage buckets were opened all treatments had ensiled with no visual mould present. The pure legume or mixes with high percentages of legume had a slightly stronger odour and darker colour compared to the mixes with larger cereal components. When fed to sheep all treatments were consumed with no residue.

\section{Discussion}

\section{Trial 1}

In this study the best treatments, in both single or multigraze options, produced total yields over $23 \mathrm{t} / \mathrm{ha} \mathrm{DM}$ in the first year and the grazed yields in the second year have a similar trend. Later sowing dates and some pugging during grazing may explain the lower yields produced in the second year.

The results from the grazing of dairy heifer calves 
showed that it is possible to grow young animals on cereal forages during winter under both multi- and singlegraze systems. The growth rates on the cereal forage treatments were comparable to that on Italian ryegrass and much higher than that achieved using traditional perennial ryegrass pastures. High per head animal growth indicate the cereal forages were of high quality. When conserved as whole-crop silage and fed as supplements to dairy cows, high milk production was achieved (Stevens et al. 2004).

The multi-graze system provided several advantages over the single-graze/resown option. Multi-graze crops matured and were harvested earlier (mid-December compared to mid-January) than single-silage crops and had lower production costs due to reduced cultivation requirement and lower sowing costs. The earlier harvest creates an opportunity for a legume/cereal silage to be sown in mid-January and harvested in March. A system comprising multi-graze cereals with a summer crop giving close to 12 months of continuous forage would produce the highest DM yield. The use of direct drilling or single pass cultivation technologies could also extend the growing times of these crops. Because of limited time between critical crop management events, this system would require very strict adherence to the calendar of operations. This produces a compromise between potential yield, quality and also the effect on subsequent crop production (de Ruiter et al. 2002).

\section{Trial 2}

The peas were the only legume to compete with the cereals and produce a forage mix with a significant legume fraction. Bean species used in this trial did not yield well and therefore do not have a place in forage systems where high yield and high legume content are primary objectives. Silage made from pea mixtures were of high quality and therefore legume crops sown for conserved feed was a good land use option. Pea/cereal yields in excess of $6 t /$ ha were produced over a 69 day period. Although the cereals were sown at low seed rates, tillering was very strong and comparatively high yields resulted. Early sowing is important to ensure good biomass growth over the January to March period.

\section{Conclusions}

Cereal forages have the ability to greatly exceed current perennial pasture forage production levels. Multi- and single-grazed systems showed no difference in the total DM produced over a 12 month period. This trial demonstrated that there was a window of opportunity for short term crops between harvest of the multi-graze silage in late-December and sowing of the subsequent crop in mid-March. This window of opportunity could be filled with a summer crop. Multi-graze crops sown in autumn have the potential to produce over $20 \mathrm{t}$ of high quality DM in 9 months. The remaining 3 -months offer the potential for a summer legume/ cereal crop of around 6 tonnes of high quality forage. This forage system will produce in excess of $25 \mathrm{t}$ of high quality forage per annum. Peas intercropped with triticale, barley or oats produced high yields with a legume proportion exceeding $50 \%$ when grown from January to March. The bean components of cereal legume mixes did not compete well with the cereals and were considered unsuitable for silage production at this time of the year.

High per head production was achieved using calves grazing the winter cereal crop. Production per head on cereals was comparable to that from Italian ryegrasses, however the per hectare production was superior on cereals. Legume/cereal silage was successfully ensiled and the resulting silage was consumed by sheep and also supported high milk production when fed as a supplement to dairy cows as did whole-crop silage produced from multi-graze DoubleTake.

\section{ACKNOWLEDGEMENTS}

The authors would like to thank Agricom (New Zealand) Ltd for their funding and support of the trial at the AgResearch Winchmore Research Station, and Winchmore farm staff for their assistance in the trial management. Thanks also to Global (Ltd) for their funding and support for the research at the AgResearch Lincoln Research farm and Todd White and David Baird for statistical analysis.

\section{REFERENCES}

de Ruiter, J.M. 2001. Growth potential of spring forage cereals for silage. Proceedings of the Agronomy Society of New Zealand 31: 99-107.

de Ruiter, J.M.; Hanson, R.; Hay, A.S.; Armstrong, K.W.; Harrison-Kirk, R.D. 2002. Whole-crop cereals for grazing and silage: balancing quality and quantity. Proceedings of the New Zealand Grassland Association 64: 181-189.

Fraser, T.J.; Vartha, E.W.1979. Experience with lucernegrass systems for sheep production. Proceedings of the New Zealand Grassland Association 41: 50-55.

Jermyn, W.A.; Hanson, R.; Scales, G.H.; Ryan, B.J. 1993. Cereals as summer and winter forage supplements for beef cattle. Proceedings of the Agronomy Society of New Zealand 28: 53-61.

Martin, R.J.; Knight, T.L. 1987. Effect of date of defoliation on yield of autumn barley sown on different dates Proceedings of the Agronomy Society of New Zealand 17: 85-89.

Moss, R.A. 1987. Production on an old irrigated pasture. Proceedings of the New Zealand Grassland Association 48: 215-218. 
Niezen, J.H.; Waghorn, G.C.; Lyons, T.B.; Corson, D.C. 1998. The potential benefits of ensiling the forage legume sulla compared with pasture. Proceedings of the New Zealand Grassland Association 60: 105-109.
Stevens, D.R.; Platfoot, G.J.; Hyslop, M.G.; Knight, T.L.; Corson, I.D.; Littlejohn, R.J. 2004. Dairy cow production when supplemented with whole-crop cereal silages in spring and autumn. Proceedings of the New Zealand Grassland Association 66: 75-83. 